\title{
Effect of Organic Growth Regulator and Shade Percentage in The Cavendish Banana (Musa acuminata) Plantlet Acclimatization
}

\author{
Nora Augustien ${ }^{1}$, Nova Triani $1^{*}$ \\ ${ }^{1}$ Agrotechnology Department, Universitas Pembangunan Nasional “Veteran” Jawa Timur, \\ Gununganyar, Surabaya 60294, Indonesia \\ *Corresponding author. Email: novatriani.agrotek@upnjatim.ac.id
}

\begin{abstract}
Banana Cavendish is one of the varieties that is widely liked by market through the appeal of fruit and nutrient content. The preparation of a banana seedling can be through tissue culture techniques. Seedlings can be said successfully if it has passed the stage of acclimatization. Nutrition and environmental conditions should be considered in the stage of acclimatization. The aim of this research is to know the dose of Organic Growth Regulator (OGR) of compost Pterocarpus indicus leaves and the optimal shade percentage on the development of banana plantlets Cavendish tissue culture. This research used the complete randomized design factorial (CRD). The first factor is the dose of OGR of compost Pterocarpus indicus $(0 \mathrm{ml}, 50 \mathrm{ml}, 100 \mathrm{ml}, 150 \mathrm{ml}, 200$ $\mathrm{ml}$ and $250 \mathrm{ml})$. The second factor is the shade percentage $(0 \%, 25 \%, 50 \%, 75 \%$ and $100 \%)$. The method used is 30 combination treatment with 3 repeats. The results showed that there was interaction (OGR $0 \mathrm{ml}+25 \%$ shade, OGR $100 \mathrm{ml}+25 \%$ shade, OGR $150 \mathrm{ml}+25 \%$ shade, OGR $0 \mathrm{ml}+75 \%$ shade and OGR $200 \mathrm{ml}+0 \%$ shade) on the percentage parameters of seedlings growth. Organic Growth Regulator of compost Pterocarpus indicus leaves showed the best response of $100 \mathrm{ml}$ on the percentage parameters of seedlings growth, increase in crop length. The $25 \%$ shade percentage gives better results at the increase in crop length. Shade percentage $100 \%$ and OGR $250 \mathrm{ml}$ and interaction treatment of OGR $250 \mathrm{ml}+0 \%$ shade showed the bad result in all parameters.
\end{abstract}

\section{Keywords: acclimatization, OGR (organic growth regulator), Cavendish banana plantlet}

\section{INTRODUCTION}

Banana is a tropical fruit commodity that is very popular in the world. The banana producing country in ASEAN is Indonesia [1]. Bananas have a lot of nutritional content, there are carbohydrates, vitamins and minerals (potassium, magnesium, phosphorus, iron, calcium, vitamins $\mathrm{A}, \mathrm{B}$ and $\mathrm{C}$, and folic acid). One banana variety that is very popular today is the Cavendish banana. The characteristic of Cavendish banana has an attraction from its bright yellow fruit skin, yellowish white flesh, fluffier and sweet taste and fine fruit fiber. Cavendish bananas contain nutrients including riboflavin, manganese, vitamin A, vitamin B3 (niacin), vitamin B6, vitamin C, fiber, protein, iron, potassium, folate and magnesium [2].

The mass supply of Cavendish banana seeds in the current era can be overcome by unconventional methods or so-called tissue culture. The stages of tissue culture include initiation, multiplication, extension and root induction (rooting), and acclimatization. Acclimatization is the stage of transfer or transition from laboratory conditions to outside laboratory conditions. One of the critical periods in tissue culture is the acclimatization stage. The acclimatization stage is a determinant of the success of tissue culture with plant conditions that can adapt and grow in an in vivo environment [3].

The factors that influence the success in unconventional plant cultivation both in the laboratory and in the greenhouse are temperature, humidity, light, planting medium and nutrients. Tissue culture laboratory conditions are influenced by temperature and light, while in green houses, temperature and shade are between 20-90\% [4].

The problems at the acclimatization stage originate from external factors, there are the planting medium, temperature and humidity conditions. This problem caused the Cavendish banana plantlet to growth disturbances and resulted in the plantlet dying. Plantlet acclimatization requires planting media, it is the composition of soil, sand and humus. The Cavendish banana acclimatization media requires soil fertility criteria in terms of physical, chemical and biological factors. The loose planting media will be easily penetrated by the roots of the Cavendish banana plant seeds, which are still very weak in the search for nutrients [5].

According to Robinson and Sauco [5], temperature and humidity factors also require special attention at the 
acclimatization stage. When adapting Cavendish banana plantlets from the laboratory to the outside environment, it requires shade that can regulate humidity conditions so that auxins can work optimally and prevent pests and plant diseases. This shade is commonly referred to as a lid, which aims to minimize excess temperature that can cause plant seedlings to die.

The use of organic fertilizers and plant growth regulators is a solution to solve the problem of nutrient needs in soil and plants, as well as growth regulators. The results of previous research have obtained that the nutrient content of organic vegetable waste liquid fertilizer in the form of potassium $(\mathrm{K}+)$ is $\pm 2.98 \%, \mathrm{Cu}, \mathrm{Fe}$ and $\mathrm{Zn}$ and organic matter $(\mathrm{BO}) \pm 2.87 \%$, auxin is $615 \mathrm{ppm}$, and the presence of the dominance of Azotobacter sp. producing antibiotics and nitrogen-binding microorganisms [6]. Indigenous technology is technology that is widely adapted, has local content, low input and is sustainable. Through regulating organic planting media, the dosage of organic fertilizers on soil and plants is continuously studied as an indigenous technology package based on organic.

The success of the acclimatization stage depends on the plantlet, temperature, light, humidity, nutrition and media and growth regulators. Light plays a role in photosynthesis, but light that is too strong will also cause plantlets to die. Shade can be used to reduce and regulate the light that enters and is received by the plantlet. Organic growth regulators play a role in plantlet growth. Small plantlets are very susceptible to inorganic substances, so that organic growth regulators are needed for plantlet growth because they are easier to absorb and are environmentally friendly. Organic growth regulators derived from organic matter, it is compost Pterocarpus indicus leaves, have been shown to increase yield and growth of chili and corn plants. Thus, research on the effect of dosage of compost Pterocarpus indicus organic growth regulating agent and percentage of shade on the growth of Cavendish banana plantlets resulting from tissue culture is necessary.

\subsection{Related Work}

There have been several studies on the use of Pterocarpus indicus leaves as liquid organic fertilizer. Previous research regarding the organic material of Pterocarpus indicus leaves, there are:

\subsubsection{The content of Pterocarpus indicus leaf liquid compost \\ Preliminary research that has been carried out is} about the use of Pterocarpus indicus leaves. Pterocarpus indicus leaves are useful as organic liquid fertilizer. Soaking Pterocarpus indicus leaf compost with water for 14 days resulted in an $\mathrm{EC}$ value of $5.3 \mathrm{mS} / \mathrm{cm}(\mathrm{EC}=$ Electrical conductivity) $(1 \mathrm{EC}=1 \mathrm{mS} / \mathrm{cm}=700 \mathrm{ppm})$. This shows that there are dissolved cations from Pterocarpus indicus leaves liquid compost are very useful for plants [7].

\subsubsection{Application of organic liquid fertilizer compost of Pterocarpus indicus leaves}

Furthermore, the organic liquid fertilizer of Pterocarpus indicus leaf compost was applied to large red chilies as much as 1 liter / plant which was able to increase the fruit weight of chilies by $21.85 \%$ compared to inorganic fertilizers [8]. Pterocarpus indicus leaf compost organic liquid fertilizer contains $615 \mathrm{ppm}$ auxin, a number of bacteria 296.10-4 cells / $\mathrm{ml}$ and fungi 41.10-4 propagules / $\mathrm{ml}$, the dominance is growing Azotobacter sp. [9]. The addition of Thitonia sp 1-2\% to the vegetable market waste compost 1-1.5 kg increases the content of organic matter $(\mathrm{BO} \pm 2.8705 \%)$ and potassium $(\mathrm{K} \pm 2.98 \%)$ in organic fertilizer liquid compost leaves Pterocarpus indicus [6]. The effectiveness of vegetable market waste compost increased chilli production by $33 \%$, saving $75 \% \mathrm{KCl}$. In corn plants, the 31 / plant dose of Pterocarpus indicus leaf compost organic liquid fertilizer increases the production of corn kernels and saves $50 \% \mathrm{KCl}[10]$.

\subsubsection{The planting medium and the length of time of covering the Cavendish banana plantlets at the acclimatization stage \\ The status of this Cavendish banana plantlet} development activity is an advanced stage. Previously, it was found the appropriate media composition formulation for the growth and development of Cavendish banana plantlets. The acclimatization stage for Cavendish bananas until the age of 30 days after acclimatization (DAA) is recommended to use the composition of the planting medium (cocopeat + husk charcoal + soil) with a length of covering 25 DAA.

\subsection{Our Contribution}

This paper presents the doses of organic growth regulators from the organic liquid fertilizer of Pterocarpus indicus leaf compost and the percentage of shade on the growth of Cavendish banana plantlets. This study utilizes organic growth regulator (OGR) of compost Pterocarpus indicus leaves. Pterocarpus indicus leaf compost in the form of liquid organic matter. The liquid organic fertilizer of Pterocarpus indicus leaves and the percentage of shade gave an interaction result on the growth of Cavendish banana plantlets.

\subsection{Paper Structure}

The rest of the paper is organized as follows. Section 2 introduce the contents of organic Pterocarpus indicus leaf compost. Section 3 presents application of Pterocarpus indicus leaf compost organic fertilizer. Then, the planting medium and the length of time of shading the Cavendish banana plantlets at the acclimatization stage in Section 3 . Finally, Section 4 concludes the paper and presents direction for future research.

\section{MATERIALS AND METHODS}

This research was conducted from June to July 2019 at the Biotechnology Laboratory, Faculty of Agriculture, Universitas Pembangunan Nasional "Veteran" Jawa Timur. 
This study used a factorial Completely Randomized Design (CRD) with 3 replications. The first treatment was Organic Growth Regulator (OGR) Pterocarpus indicus leaf compost (K) with a treatment level of $\mathrm{K}_{0}=0 \mathrm{ml}, \mathrm{K}_{1}=50 \mathrm{ml}, \mathrm{K}_{2}=$ $150 \mathrm{ml}, \mathrm{K}_{3}=200 \mathrm{ml}$ and $\mathrm{K}_{4}=250 \mathrm{ml}$. The second treatment is percentage shade $(\mathrm{P})$ with treatment level $\mathrm{P}_{0}=0 \%, \mathrm{P}_{1}=$ $25 \%, \mathrm{P}_{2}=50 \%, \mathrm{P}_{3}=75 \%$ and $\mathrm{P}_{4}=100 \%$. The follow-up test used was the Least Significant Difference (LSD) 5\%. The tools used in this study were analytical scales, autoclave, tweezers, spatula, ruler, hand sprayer. The materials used are Cavendish banana plantlets, Organic Growth Regulator Pterocarpus indicus leaf compost, shade, cocopeat, husk charcoal, sand, $12 \times 10 \mathrm{~cm}$ polybags, plastic, rope, fungicide and paper.

The research implementation includes preparation of planting media, growth regulators and shade, preparation of plantlets according to criteria, planting, shade installation, giving growth regulators, maintenance and observation.

\section{RESULTS AND DISCUSSION}

\subsection{Percentage of Growing Plantlet (\%)}

Table 1 shows that at the age of 7 daa there was an interaction between the growth regulators of Pterocarpus indicus leaf compost and percentage of shade. All interaction treatments showed that the percentage of seedlings was not significantly different, but the treatment with a growth regulator of $250 \mathrm{ml}$ and $0 \%$ shade showed very low yields compared to other treatments.

Table 1. Average Percentage of Cavendish Banana Plantlet (\%) Growth in the Treatment of Organic Growth Regulator (OGR) Pterocarpus indicus Leaves Compost and Shade Percentage at 7 DAA

\begin{tabular}{|c|c|}
\hline Treatment & $\begin{array}{c}\text { Percentage of Plantlet Growth (\%) } \\
7 \text { (DAA) }\end{array}$ \\
\hline OGR $0 \mathrm{ml}+$ shade percentage $0 \%$ & 100 \\
\hline OGR $0 \mathrm{ml}+$ shade percentage $25 \%$ & 100 \\
\hline OGR $0 \mathrm{ml}+$ shade percentage $50 \%$ & 100 \\
\hline OGR $0 \mathrm{ml}+$ shade percentage $75 \%$ & 100 \\
\hline OGR $0 \mathrm{ml}+$ shade percentage $100 \%$ & 88,89 b \\
\hline OGR50 $\mathrm{ml}+$ shade percentage $0 \%$ & $66,67 \mathrm{ab}$ \\
\hline OGR $50 \mathrm{ml}+$ shade percentage $25 \%$ & $77,78 \mathrm{ab}$ \\
\hline OGR $50 \mathrm{ml}+$ shade percentage $50 \%$ & 88,89 b \\
\hline OGR $50 \mathrm{ml}+$ shade percentage $75 \%$ & 100 \\
\hline OGR $50 \mathrm{ml}+$ shade percentage $100 \%$ & 88,89 b \\
\hline OGR $100 \mathrm{ml}+$ shade percentage $0 \%$ & $100 \quad b$ \\
\hline OGR $100 \mathrm{ml}+$ shade percentage $25 \%$ & 100 \\
\hline OGR $100 \mathrm{ml}+$ shade percentage $50 \%$ & 88,89 b \\
\hline OGR $100 \mathrm{ml}+$ shade percentage $75 \%$ & $100 \quad \mathrm{~b}$ \\
\hline OGR $100 \mathrm{ml}+$ shade percentage $100 \%$ & 88,89 b \\
\hline OGR $150 \mathrm{ml}+$ shade percentage $0 \%$ & 100 \\
\hline OGR $150 \mathrm{ml}+$ shade percentage $25 \%$ & 100 \\
\hline OGR $150 \mathrm{ml}+$ shade percentage $50 \%$ & $88,89 \quad \mathrm{~b}$ \\
\hline OGR $150 \mathrm{ml}+$ shade percentage $75 \%$ & $77,78 \quad a b$ \\
\hline OGR $150 \mathrm{ml}+$ shade percentage $100 \%$ & $100 \quad \mathrm{~b}$ \\
\hline OGR $200 \mathrm{ml}+$ shade percentage $0 \%$ & $88,89 \quad b$ \\
\hline OGR $200 \mathrm{ml}+$ shade percentage $25 \%$ & $100 \quad b$ \\
\hline OGR $200 \mathrm{ml}+$ shade percentage $50 \%$ & 88,89 b \\
\hline OGR $200 \mathrm{ml}+$ shade percentage $75 \%$ & 100 \\
\hline OGR $200 \mathrm{ml}+$ shade percentage $100 \%$ & 100 \\
\hline OGR $250 \mathrm{ml}+$ shade percentage $0 \%$ & 55,56 a \\
\hline OGR $250 \mathrm{ml}+$ shade percentage $25 \%$ & $100 \quad \mathrm{~b}$ \\
\hline OGR $250 \mathrm{ml}+$ shade percentage $50 \%$ & $66,67 \mathrm{ab}$ \\
\hline OGR $250 \mathrm{ml}+$ shade percentage $75 \%$ & $100 \quad b$ \\
\hline OGR $250 \mathrm{ml}+$ shade percentage $100 \%$ & 88,89 b \\
\hline LSD 5\% & 23,13 \\
\hline
\end{tabular}

Note: The numbers followed by the same letter are not significantly different at the LSD test level $\alpha=0.05$. 
Table 2. Average Percentage of Cavendish Banana Plantlet (\%) Growth in the Treatment of Organic Growth Regulator (OGR) Pterocarpus indicus Leaves Compost and Shade Percentage at 14 daa and 21 daa

\begin{tabular}{|c|c|c|}
\hline Treatment & \multicolumn{2}{|c|}{ Percentage of Plantlet Growth (\%) } \\
\cline { 2 - 3 } Organic Growth Regulator & $14(\mathrm{daa})$ & $21($ daa $)$ \\
\hline OGR 0 ml & $68,84 \mathrm{ab}$ & 31,11 \\
\hline OGR $50 \mathrm{ml}$ & $60,00 \mathrm{ab}$ & 26,67 \\
\hline OGR $100 \mathrm{ml}$ & $75,60 \mathrm{~b}$ & 24,44 \\
\hline OGR $150 \mathrm{ml}$ & $57,80 \mathrm{ab}$ & 22,22 \\
\hline OGR $200 \mathrm{ml}$ & $57,78 \mathrm{ab}$ & 13,33 \\
\hline OGR $250 \mathrm{ml}$ & $35,56 \mathrm{a}$ & not real \\
\hline LSD 5\% & 37,923 & 29,63 \\
\hline Shade percentage 0\% & 50,00 & 29,63 \\
\hline Shade percentage 25\% & 72,22 & 18,52 \\
\hline Shade percentage 50\% & 61,11 & 20,37 \\
\hline Shade percentage 75\% & 53,72 & 16,67 \\
\hline Shade percentage $100 \%$ & 59,26 & not real \\
\hline LSD 5\% & not real & \\
\hline
\end{tabular}

Note: The numbers followed by the same letter are not significantly different at the LSD test level $\alpha=0.05$.

Table 2 show that the growth regulators of Pterocarpus indicus leaf compost showed an effect on the percentage of growth of the 7 daa Cavendish banana plant seedlings. OGR treatment of $100 \mathrm{ml}$ Pterocarpus indicus leaf compost was not significantly different from OGR 0 $\mathrm{ml}, 50 \mathrm{ml}, 150 \mathrm{ml}$ and $200 \mathrm{ml}$. OGR treatment of $250 \mathrm{ml}$ Pterocarpus indicus leaf compost showed the lowest yield compared to other treatments. The treatment of growth regulators and shade showed the same response at the 21 daa observation. This treatment response resulted in an average value of the percentage of seedlings that did not differ significantly.

\subsection{Increase in Plant Length $(\mathrm{cm})$}

Table 3. Average of Increase in Plant Length Cavendish Banana Plantlet $(\mathrm{cm})$ in the Treatment of Organic Growth Regulator (OGR) Pterocarpus indicus Leaves Compost and Shade Percentage

\begin{tabular}{|c|c|c|c|}
\hline \multirow{2}{*}{ Treatment } & \multicolumn{3}{|c|}{ Increase in Plant Length (cm) } \\
\cline { 2 - 4 } & $7(\mathrm{daa})$ & $14(\mathrm{daa})$ & 21 (daa) \\
\hline Organic Growth Regulator & 0,72 & 0,22 & $0,19 \mathrm{~b}$ \\
\hline OGR 0 ml & 0,60 & 0,31 & $0,12 \mathrm{ab}$ \\
\hline OGR 50 ml & 0,63 & 0,19 & $0,12 \mathrm{ab}$ \\
\hline OGR 100 ml & 0,62 & 0,31 & $0,06 \mathrm{a}$ \\
\hline OGR 150 ml & 0,67 & 0,13 & $0,03 \mathrm{a}$ \\
\hline OGR 200 ml & 0,62 & not real & 0,12 \\
\hline OGR 250 ml & not real & $0,15 \mathrm{a}$ & 0,10 \\
\hline LSD 5\% & 0,75 & $0,27 \mathrm{ab}$ & 0,09 \\
\hline Shade percentage & 0,57 & $0,15 \mathrm{a}$ & 0,14 \\
\hline Shade percentage 0\% & 0,63 & $0,40 \mathrm{~b}$ & 0,12 \\
\hline Shade percentage 25\% & 0,82 & $0,16 \mathrm{a}$ & 0,08 \\
\hline Shade percentage 50\% & 0,47 & 0,22 & not real \\
\hline Shade percentage 75\% & not real & \multicolumn{2}{|c|}{} \\
\hline Shade percentage 100\% & \multicolumn{3}{|l|}{}
\end{tabular}

Table 3. showed that the treatment of Pterocarpus indicus leaf compost growth regulators, the parameters of plant length increase were not significantly different at the age of 7 and 14 daa, but observations of age 21 daa showed a significantly different response. The results of the smallest significant difference test at the age of 21 daa showed that 
the growth regulator $0 \mathrm{ml}$ was not significantly different from $50 \mathrm{ml}, 100 \mathrm{ml}$ and $150 \mathrm{ml}$. The doses of growth regulators such as $200 \mathrm{ml}$ and $250 \mathrm{ml}$ gave a negative response to the growth of plantlet seedlings. Excess application of growth regulators can cause plants to do physiological deterioration or stagnation. Shade treatment showed that the age of 7 daa and 21 daa was not significantly different, while the age of 14 daa showed that $75 \%$ shade was not significantly different from $25 \%$ shade.

\subsection{Increase in Amount of Leaves}

Table 4. show that the treatment of Pterocarpus indicus leaf compost and shade percentage until the age of 21 daa did not respond well to the increase in the number of leaves plantlet Cavendish banana.

Table 4. Average of Increase in Amount of Leaves Cavendish Banana Plantlet in the Treatment of Organic Growth Regulator (OGR) Pterocarpus indicus Leaves Compost and Shade Percentage

\begin{tabular}{|c|c|c|l|}
\hline \multirow{2}{*}{ Treatment } & \multicolumn{3}{|c|}{ Increase in Amount of Leaves } \\
\cline { 2 - 4 } & 7 (daa) & $14($ daa $)$ & 21 (daa) \\
\hline Organic Growth Regulator & 0,00 & 0,00 & 0,00 \\
\hline OGR 0 ml & 0,00 & 0,00 & 0,00 \\
\hline OGR 50 ml & 0,00 & 0,00 & 0,00 \\
\hline OGR 100 ml & 0,00 & 0,00 & 0,00 \\
\hline OGR 150 ml & 0,00 & 0,00 & 0,00 \\
\hline OGR 200 ml & 0,00 & 0,00 & 0,00 \\
\hline OGR 250 ml & not real & not real & not real \\
\hline LSD 5\% & 0,00 & 0,00 & 0,00 \\
\hline Shade percentage & 0,00 & 0,00 & 0,00 \\
\hline Shade percentage 0\% & 0,00 & 0,00 & 0,00 \\
\hline Shade percentage 25\% & 0,00 & 0,00 & 0,00 \\
\hline Shade percentage 50\% & 0,00 & 0,00 & 0,00 \\
\hline Shade percentage 75\% & not real & not real & not real \\
\hline Shade percentage 100\% & \multicolumn{2}{l}{} \\
\hline LSD 5\% &
\end{tabular}

\subsection{Percentage of Mortality (\%)}

Table 5. shows that the mortality percentage of Cavendish banana plantlet aged 21 daa was $100 \%$ mortality in OGR treatment $0 \mathrm{ml}+0 \%$ shade, $0 \mathrm{ml}$ OGR $+100 \%$ shade, $100 \mathrm{ml} \mathrm{OGR}+50 \%$ shade, $200 \mathrm{ml} \mathrm{OGR}+75 \%$ shade , OGR $250 \mathrm{ml}+0 \%$ shade, OGR $250 \mathrm{ml}+25 \%$ shade and OGR $250 \mathrm{ml}+50 \%$ shade.

The lowest percentage of mortality occurred in the interaction of OGR $0 \mathrm{ml}+25 \%$ shade, $0 \mathrm{ml} \mathrm{OGR}+50 \%$ shade, $100 \mathrm{ml}$ OGR $+25 \%$ shade, $150 \mathrm{ml} \mathrm{OGR}+25 \%$ shade and $200 \mathrm{ml} \mathrm{OGR}+0 \%$ shade. This shows that giving OGR at low doses requires $25 \%$ and $75 \%$ shade percentage, while giving OGR with high doses requires a low percentage of shade between $0 \%$ and $25 \%$.

Acclimatization is a critical period in tissue culture. Acclimatization is said to be successful if the plantlets are able to pass through the critical period and produce seedlings that are ready for planting. A common aberration in in-vitro culture is that the plantlets in the bottle have some physiological deterioration in organ function. The success of the acclimatization of in vitro cultured plants is influenced by the size of the seedlings, roots, media, humidity, and pest attacks [11][12].
The physiological deterioration that occurred in the Cavendish banana plantlet as a result of the study was abnormal or broken roots. This makes it difficult to absorb water and nutrients so that it is easy to death. Fact there are no living plantlets, this is due to the loss of stomata function and the thinning of the leaf cuticles (burnt leaves) [13][14][15]. After several days of acclimatization, the plantlets had rot and death.

The results of the research that have been processed using analysis of variance show that there is an interaction between the treatment of growth regulators and shade percentage. The first interaction occurred in the parameters of the percentage of seedlings growing in all treatments which were not significantly different except for the OGR treatment $250 \mathrm{ml}+0 \%$ shade. Giving too much OGR causes the plants to be in saturated conditions and causes the plant roots to rot. The interaction of growth regulators and shade treatment occurred in the mortality of Cavendish banana plantlets aged 4 to 13 and 21 days. The lowest mortality was shown by OGR treatment $0 \mathrm{ml}+25 \%$, OGR $100 \mathrm{ml}+25 \%$, OGR $150 \mathrm{ml}+25 \%$, OGR $0 \mathrm{ml}+75 \%$ and OGR $200 \mathrm{ml}+$ $0 \%$ and the highest mortality occurred in treatment OGR $250 \mathrm{ml}+0 \%$. 
Table 5. Average of Percentage Mortality Cavendish Banana Plantlet in the Treatment of Organic Growth Regulator (OGR) Pterocarpus indicus Leaves Compost and Shade Percentage

\begin{tabular}{|c|c|}
\hline Treatment & $\begin{array}{l}\text { Mortality Percentage (\%) } \\
21 \text { (daa) }\end{array}$ \\
\hline OGR $0 \mathrm{ml}+$ shade percentage $0 \%$ & $100 \mathrm{~b}$ \\
\hline OGR $0 \mathrm{ml}+$ shade percentage $25 \%$ & 55,56 a \\
\hline OGR $0 \mathrm{ml}+$ shade percentage $50 \%$ & $66,67 \mathrm{ab}$ \\
\hline OGR $0 \mathrm{ml}+$ shade percentage $75 \%$ & 55,56 a \\
\hline OGR $0 \mathrm{ml}+$ shade percentage $100 \%$ & $100 \mathrm{~b}$ \\
\hline OGR $50 \mathrm{ml}+$ shade percentage $0 \%$ & $88,87 \quad a b$ \\
\hline OGR $50 \mathrm{ml}+$ shade percentage $25 \%$ & $88,87 \mathrm{ab}$ \\
\hline OGR $50 \mathrm{ml}+$ shade percentage $50 \%$ & $66,67 \mathrm{ab}$ \\
\hline OGR $50 \mathrm{ml}+$ shade percentage $75 \%$ & $66,67 \mathrm{ab}$ \\
\hline OGR $50 \mathrm{ml}+$ shade percentage $100 \%$ & $77,78 \mathrm{ab}$ \\
\hline OGR $100 \mathrm{ml}+$ shade percentage $0 \%$ & $66,67 \mathrm{ab}$ \\
\hline OGR $100 \mathrm{ml}+$ shade percentage $25 \%$ & 55,56 a \\
\hline OGR $100 \mathrm{ml}+$ shade percentage $50 \%$ & $100 \mathrm{~b}$ \\
\hline OGR $100 \mathrm{ml}+$ shade percentage $75 \%$ & 77,78 ab \\
\hline OGR $100 \mathrm{ml}+$ shade percentage $100 \%$ & 77,78 ab \\
\hline OGR $150 \mathrm{ml}$ +shade percentage $0 \%$ & $66,67 \mathrm{ab}$ \\
\hline OGR $150 \mathrm{ml}+$ shade percentage $25 \%$ & 55,56 a \\
\hline OGR $150 \mathrm{ml}+$ shade percentage $50 \%$ & 88,89 ab \\
\hline OGR $150 \mathrm{ml}+$ shade percentage $75 \%$ & $88,89 \quad$ ab \\
\hline OGR $150 \mathrm{ml}+$ shade percentage $100 \%$ & $88,89 \quad a b$ \\
\hline OGR $200 \mathrm{ml}+$ shade percentage $0 \%$ & 55,56 a \\
\hline OGR $200 \mathrm{ml}+$ shade percentage $25 \%$ & $77,78 \quad a b$ \\
\hline OGR $200 \mathrm{ml}+$ shade percentage $50 \%$ & $77,78 \mathrm{ab}$ \\
\hline OGR $200 \mathrm{ml}+$ shade percentage $75 \%$ & 100 \\
\hline OGR $200 \mathrm{ml}+$ shade percentage $100 \%$ & $88,89 \quad$ ab \\
\hline OGR $250 \mathrm{ml}$ +shade percentage $0 \%$ & 100 \\
\hline OGR $250 \mathrm{ml}+$ shade percentage $25 \%$ & 100 \\
\hline OGR $250 \mathrm{ml}+$ shade percentage $50 \%$ & 100 \\
\hline OGR $250 \mathrm{ml}+$ shade percentage $75 \%$ & 88,89 ab \\
\hline OGR $250 \mathrm{ml}+$ shade percentage $100 \%$ & $66,67 \mathrm{ab}$ \\
\hline LSD 5\% & 23,13 \\
\hline
\end{tabular}

Note: The numbers followed by the same letter are not significantly different at the LSD test level $\alpha=0.05$.

Organic growth regulator can be obtained both naturally and synthetically. Generally, natural OGR is readily available in nature and comes from organic materials, for example coconut water, cow urine, and extraction from plant parts [16]. The application of exogenous OGR in plants can function to spur the formation of phytohormones, so that it can encourage a biochemical activity. Compounds are transformed into all parts of the plant so that they can affect the growth or physiological processes of the plant [17].

According to Mulyono [18], it is said that the direction and quality of plant growth and development are largely determined by growth regulators. The successful growth of seedlings during the acclimatization period requires growth regulators that can stimulate roots, including growth regulators for auxin.
The treatment response of growth regulators showed an effect on the percentage parameters of 14 daa seedlings. The results of the smallest significant difference test showed that all treatments showed no significant difference except for the $250 \mathrm{ml}$ treatment. The next parameter, it was the length of the 21 daa plant, showed that the results without growth regulators were not significantly different from $50 \mathrm{ml}, 100 \mathrm{ml}$ and $150 \mathrm{ml}$. The growth regulator 100 $\mathrm{ml}$ was the best dose among the dosing treatments by showing the lowest percentage of mortality results at the age of 14 daa to 19 daa.

Growth regulators from Pterocarpus indicus plants contain auxin which can support plant growth [7]. Provision of appropriate growth regulators, both in composition and concentration, can lead to better plant growth and development. Auxin growth regulators at high levels are more inhibiting than stimulating growth [19]. Auxin is a 
compound with the characteristics of having the ability to support cell extension at the shoot, the large amount of auxin content in plants greatly affects plant growth [20]. This supports the elongation of leaves which results in plant length.

Shade percentage treatment response showed significant differences in the plant length parameters aged 14 daa. The smallest significant difference test result shows that $75 \%$ is not significantly different from $25 \%$. The percentage of mortality parameter showed that the dose of $25 \%$ was very good at the age of 18 daa and 19 daa. These results indicate a low percentage of mortality compared to other treatments.

The percentages are $0 \%$ (without shade), 25\% (1 shade layer), $50 \%$ (2 shade layers), $75 \%$ (3 shade layers) and $100 \%$ (4 shade layers). The shade level of one shade layer provides better growth compared to the shade of two to 4 layers of shade. It is assumed that one layer of shade is the optimal environmental conditions for maximum plant growth. The percentage of shade from two to 4 layers of shade has low light intensity, so the plant will lack light which causes too much respiration and etiolation. On the other hand, without shade, the light intensity is too high and the temperature is high so that it can suppress the working power of the auxin.

The shade provides benefits for regulating the intensity of the sun's radiation, high and low temperatures, humidity and wind resistance [21]. Khoiri [22] stated that shade with different percentages of shade can result in differences in the microclimate environment, including light intensity, air temperature, soil temperature and humidity. From this research, the average temperature and humidity $0 \%$ shade is $\left(27.57^{\circ} \mathrm{C} ; 77\right), 25 \%$ shade is $\left(26.17^{\circ} \mathrm{C}\right.$; $66), 50 \%$ shade is $\left(26.57^{\circ} \mathrm{C} ; 69\right), 75 \%$ shade is $\left(27.53^{\circ} \mathrm{C}\right.$; $65), 25 \%$ shade is $\left(27^{\circ} \mathrm{C} ; 70\right)$.

\section{CONCLUSION}

The results showed that there were interactions (OGR $0 \mathrm{ml}+25 \%$, OGR $100 \mathrm{ml}+25 \%$, OGR $150 \mathrm{ml}+$ $25 \%$, OGR $0 \mathrm{ml}+75 \%$ and OGR $200 \mathrm{ml}+0 \%$ ) on the parameters of the percentage of plantlet to grow and the lowest mortality rate. Pterocarpus indicus leaf compost organic growth regulator showed the best response, was 100 $\mathrm{ml}$ on the parameters of the percentage of plantlet growth, plant length and the lowest mortality rate. The percentage of $25 \%$ shade gave better yields at the length of the plant and the lowest mortality. The interaction between OGR 250 $\mathrm{ml}+0 \%$, OGR $250 \mathrm{ml}$ and $100 \%$ shade showed the worst response in all parameters.

\section{ACKNOWLEDGMENT}

This work was supported by LPPM Universitas Pembangunan Nasional "Veteran" Jawa Timur.

\section{REFERENCES}

[1] T. N. Hidayati and S. Suhartini, "Analisis Daya Saing Ekspor Pisang (Musa Paradiaca L.) Indonesia di Pasar Asean dalam Menghadapi Masyarakat Ekonomi Asean (MEA)," J. Ekon. Pertan. dan Agribisnis, vol. 2, no. 4, pp. 267278, 2018, doi: 10.21776/ub.jepa.2018.002.04.210.21776/ub.je pa.2018.002.04.2.

[2] B. Shintia, "Analisis Keputusan Konsumen Terhadap Pembelian Pisang Cavendish (Musa acuminata) di Brastagi Supermarket Medan," Skripsi Univ. Muhammadiyah Sumatera Utara, pp. 1-85, 2019, doi: 10.1145/1390630.1390641.

[3] F. Kusmiyati et al., "Penerapan Teknologi Aklimatisasi Bibit Pisang Hasil Kultur Jaingan di Kecamatan Bandar Kabupaten Batang," $J$. DIANMAS, vol. 8, no. 1, pp. 39-46, 2019.

[4] R. R. Putra, I. S. Mercuriani, and E. Semiarti, "Pengaruh Cahaya dan Temperatur Terhadap Pertumbuhan Tunas dan Profil Protein Tanaman Anggrek Phalaenopsis amabilis Transgenik Pembawa Gen Ubipro::PaFT," Bioeksperimen J. Penelit. Biol., vol. 2, no. 2, p. 76, 2016, doi: 10.23917/bioeksperimen.v2i2.2483.

[5] J. C. Robinson and V. G. Sauco, "Weaning (acclimatization) of in vitro-produced banana plants," Fruits, vol. 64, pp. 325-332, 2009, doi: 10.1051/fruits.

[6] N. Augustien, R. Hidayat, and W. Mindari, "Penambahan Thitonia sp pada Kompos Sampah Pasar Sayur Terhadap Peningkatan Unsur K+ dan BO," in Laporan Penelitian FP UPN "Veteran" Jawa Timur, 2009.

[7] N. Augustien and W. S. Harijani, "Perendaman dan Pengujian Nilai Electrical Conductivyty pada Teh Kompos Daun Sono.," in Laporan Penelitian FP UPN “Veteran" Jawa Timur, 2005.

[8] N. Augustien and W. S. Harijani, "Pemberian Teh kompos Daun Sono pada Tanaman Cabe besar," in Laporan Penelitian FP UPN "Veteran" Jawa Timur, 2006.

[9] N. Augustien, Hidajat, and Wahyuni, "Biodiversitas Mikroorganisme Teh Kompos Sampah Pasar Sayur," in Laporan Penelitian Fundamental DIKTI, 2008.

[10] N. Augustien, "Efektivitas Teh Kompos Sampah Sayur dan Thitonia sp terhadap Peningkatan Produksi Tanaman Cabe besar," in Laporan Penelitian FP UPN "Veteran" Jawa Timur, 2010.

[11] C. Gunarsih, B. S. Purwoko, I. S. Dewi, and D. M. Syukur, "Regenerasi dan Aklimatisasi Kultur Antera Enam Persilangan F1 Padi Sawah," J. 
Agron. Indones. (Indonesian J. Agron., vol. 44, no. 2, p. 133, 2016, doi: 10.24831/jai.v44i2.13479.

[12] D. Sukmadijaya, D. Dinarti, and Y. Isnaini, "Pertumbuhan Planlet Kantong Semar (Nepenthes rafflesiana Jack.) pada Beberapa Media Tanam Selama Tahap Aklimatisasi The growing of Kantong Semar (Nepenthes rafflesiana Jack.) planlet in several media during acclimatization stage," J. Hort. Indones., vol. 4, no. 3, pp. 124-130, 2013.

[13] S. Chandra, R. Bandopadhyay, V. Kumar, and R. Chandra, "Acclimatization of tissue cultured plantlets: From laboratory to land," Biotechnol. Lett., vol. 32, no. 9, pp. 1199-1205, 2010, doi: 10.1007/s10529-010-0290-0.

[14] J. E. Preece and E. G. Sutter, "Acclimatization of micropropagated plants to the greenhouse and field," Micropropagation, pp. 71-93, 1991, doi: 10.1007/978-94-009-2075-0_5.

[15] J. Pospisilova, I. Ticha, P. Kadlecek, D. Haisel, and S. Plzakova, "Acclimatization of micropropagated plants to ex vitro conditions," Biologia Plantarum, vol. 42, no. 4. pp. 481-497, 1999.

[16] Y. Zhao, "Auxin biosynthesis and its role in plant development," Annu. Rev. Plant Biol., vol. 61, pp. 49-64, 2010, doi: 10.1146/annurevarplant-042809-112308.

[17] S. Djamhari, "Memecah Dormansi Rimpang Temulawak (Curcuma xanthorrhiza ROXB) Menggunakan Larutan Atonik dan Stimulasi
Perakaran dengan Aplikasi Auksin," J. Sains dan Teknol. Indones., vol. 12, no. 1, pp. 66-70, 2012, doi: 10.29122/jsti.v12i1.852.

[18] D. Mulyono, "Pengaruh Kombinasi Intensitas Naungan Dengan Zat Pengatur Tumbuh Indole Butiric Acid (Iba), Naphthalene Acetic Acid (Naa), dan Vitamin B1 dalam Aklimatisasi Pertumbuhan Bibit Gaharu (Aquilaria beccariana)," J. Sains dan Teknol. Indones., vol. 14, no. 3, pp. 167-173, 2013, doi: 10.29122/jsti.v14i3.922.

[19] H. Sudrajad, N. R. Wijaya, and D. Suharto, "Pengaruh Benzil Amino Purin dan Naftalene Acetic Acid Terhadap Kalus Pulesari (Alyxia reinwardtii BI)," vol. 18, no. 1, pp. 22-27, 2003.

[20] M. Estelle, "The plant hormone auxin: Insight in sight," BioEssays, vol. 14, no. 7, pp. 439-444, 1992, doi: 10.1002/bies.950140703.

[21] A. T. Aulia Nurbaiti Mansyur, Sugeng Triyono, "Pengaruh Naungan Terhadap Pertumbuhan Sawi (Brassica Juncea L.). Pada Sistem Hidroponik DFT (Deep Flow Technique)," Psychol. Appl. to Work An Introd. to Ind. Organ. Psychol. Tenth Ed. Paul, vol. 53, no. 9, pp. 1689-1699, 2014, doi: 10.1017/CBO9781107415324.004.

[22] M. Khoiri, "Pengaruh Naungan Terhadap Pertumbuhan dan Laju Fotosintesis Tanaman Cabe Merah (Capsicum annuum L.) sebagai Salah Satu Sumber Belajar Biologi,” p. 8, 2010. 